\title{
Experimental and Analytical Studies on Lightning Surge Characteristics of a Buried Bare Wire
}

\author{
Hideki Motoyama Member (CRIEPI, motoyama@criepi.denken.or.jp)
}

Keywords: lightning, lightning surge, surge analysis, buried bare wire, grounding resistance

\section{Introduction}

This paper describes experimental and analytical studies on lightning surge characteristics of a buried bare wire. The lightning surge characteristics of the ground net have influence on induced overvoltages in low-voltage and control circuits of power stations and substations. In general, the ground net consists of multiphase buried bare wires. Therefore, the examinations for modeling of a buried bare wire have been carried out. However, these examinations have the following problems:

(1) The analytical model of a buried bare wire is based on the Sunde's theoretical formulas. However, it is not clear whether the Sunde's theoretical formulas can reproduce the actual electromagnetic transient response of a buried bare wire and ground net, or not.

(2) Comparison between calculated results by the proposed models and experimental results of the actual buried bare wire is insufficient. Therefore, it is not possible to apply the proposed models to practical use.

To solve these problems, the lightning surge characteristics of a buried bare wire in various experimental conditions are measured with the experimental circuit shown in Fig. 1. The validity of the Sunde's formulas is examined through the comparison between the experimental results and the calculated results by the Sunde's formulas.

\section{Conclusions}

The following conclusions are obtained from the examinations:

(1) The maximum value of Ground Potential Rise (GPR) of a buried bare wire, which appears at the beginning of time, is almost same regardless of ground resistivity or length of the wires. The characteristics show that the concept of surge impedance is approved to a buried bare wire as well as an aerial line (Figs. 2 and $3)$.

(2) The current propagation velocity of a buried bare wire is

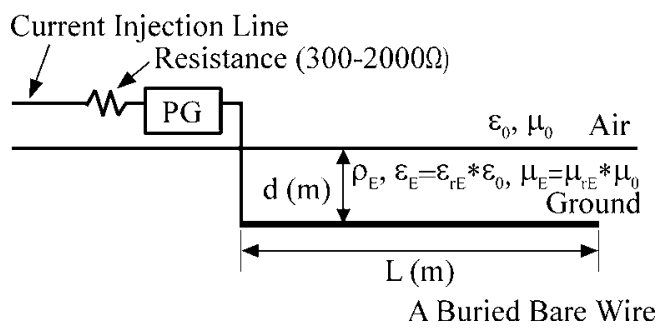

Fig. 1. Experimental circuit
$70-80 \mathrm{~m} / \mu \mathrm{s}$ from the simultaneous measurement of the current of the buried bare wire at each part.

(3) To confirm the validity of the Sunde's theoretical formulas, the experimental results and the calculated results by the theoretical formulas are compared. The calculated results can almost reproduce the experimental results of the buried bare wire (Fig. 4).

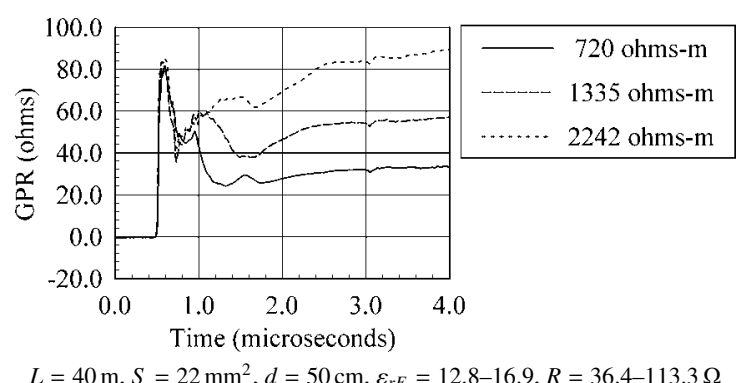

Fig. 2. Effects of ground resistivity

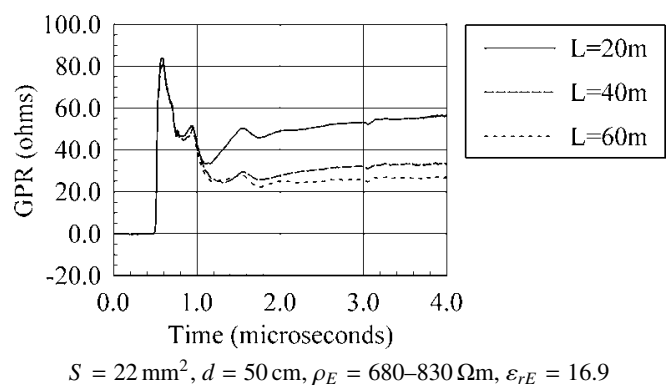

Fig. 3. Effects of wire length

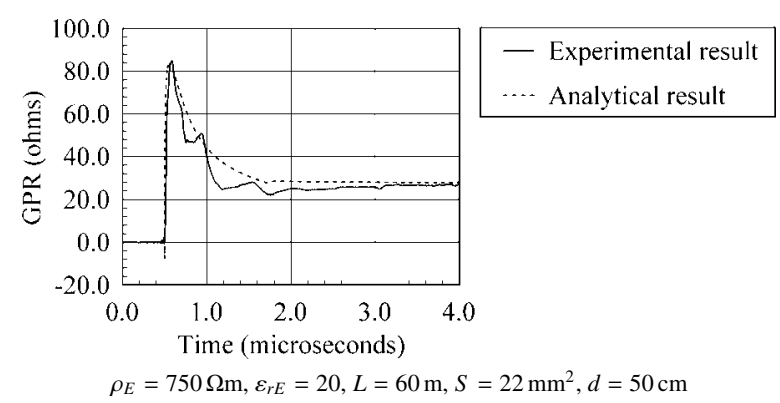

Fig. 4. Compared results between experimental and calculated results 


\title{
埋設地線の雷サージ特性に関する実験的・解析的検討
}

\author{
正 員 本山 英器* \\ Experimental and Analytical Studies on Lightning Surge \\ Characteristics of a Buried Bare Wire \\ Hideki Motoyama*, Member
}

\begin{abstract}
Lightning surge analysis is very important from the viewpoint of insulation design of transmission lines and substations. Lightning surge analysis has many parameters, which include lightning surge characteristics of transmission towers, back flashover phenomena at an arcing horn, characteristics of footing resistance, effects of corona wave deformation, characteristics of electromagnetic fields caused by lightning, and other parameters. This paper describes experimental and analytical studies on lightning surge characteristics of a buried bare wire. The measurement of the lightning surge characteristics of the buried bare wire is carried out under various experimental conditions. The experimental parameters controlled in these experiments include earth resistance, length of the buried bare wire and waveform of the injected current. The measured results are compared with analytical results based on the theoretical study by Sunde. A comparison of the measured results with the analytical results shows good agreement.
\end{abstract}

キーワード: 雷, 雷サージ, サージ解析, 埋設地線, 接地抵抗

Keywords: lightning, lightning surge, surge analysis, buried bare wire, grounding resistance

\section{1. はじめに}

送電線や変電所から構成される複雑な電力系統の合理的 かつ経済的な絶縁設計を計るためには，電力系統で発生す る雷，開閉，地絡サージなどの異常現象をできるだけ正確 に把握する必要がある。特に, 雷サージは, 電力機器の絶 縁レベルを決定する上で重要な要素であり, 雷撃時に発生 する雷サージをできるだけ正確に予測することが重要な課 題となっている。

電力系統に発生する雷サージを予測する場合，送電線へ の雷撃特性, 鉄塔の雷サージ特性, アークホーンのフラッシ オーバ特性, 塔脚や接地網の接地抵抗特性など, 各種のパラ メータが存在し, これらのパラメータの実験的・理論的検 討や数值モデル化の試みがなされている(1)(2)。特に, 接地網 や埋設地線の過渡接地抵抗特性は, 変電所の低圧・制御回 路で発生する雷サージを決定する上で，極めて重要なパラ メータであり, 古くから多くの研究が行われてきた ${ }^{(3) \sim(16) 。 ~}$ 接地網や埋設地線の過渡接地抵抗特性に関しては, 古く は, Sunde ${ }^{(3)}$ による理論解析が行われており, この研究結 果に基づく過渡接地抵抗特性解析モデルが提案されている。 また, 近年, Maxwell 方程式を直接計算する数值電磁界解

\footnotetext{
* (財) 電力中央研究所電力技術研究所

干 240-0196 横須賀市長坂 2-6-1

Electric Power Engineering Research Laboratory, CRIEPI

2-6-1, Nagasaka, Yokosuka 240-0196
}

析手法をこれらの過渡接地抵抗特性の解析に適用した検討 も行われつつある。

この様に, 接地網や埋設地線の過渡接地抵抗特性に関す る研究は今日に至るまで進められてきたが，未だに問題が 解決されていない。この理由として, 下記の事項が挙げら れる。

（1）接地網や埋設地線の過渡接地抵抗特性に関する実験 結果が極めて少ない。特に, 大地の構造の複雑さから, 種々 の大地抵抗率下で実験結果を比較した例はほとんどない。

(2) 接地網や埋設地線の過渡接地抵抗特性に関する研 究の多くが理論的アプローチであるため, 実験結果との対 比不足から，その解析精度が十分には確認できていない。

（3）接地網や埋設地線の過渡接地抵抗特性に関する実 験では, 電流印加点の過渡電位上昇に着目した実験が行わ れている。しかしながら, 接地網や埋設地線を分布定数回 路と考えると, 各測定点における電圧・電流分布が大きな 問題となる。この点に関する実験結果はほとんどない。

本論文は, これらの問題を解決するために, 埋設地線の 過渡特性に着目し, 直角波電流印加時の電圧・電流特性の 詳細測定から, 埋設地線の過渡接地抵抗特性を実験的に明 らかにする。また, 大地抵抗率の与える影響についても実 験的に明らかにする。さらに, 接地抵抗の周波数特性につ いても実験的に明らかにする。これらの実験結果と Sunde の理論式との比較から, 埋設地線の過渡接地抵抗特性のモ デル化について考察を行う。 


\section{2. 実験方法}

埋設地線に直角波電流を印加した時に埋設地線各部で発 生する過渡電位上昇（Transient Ground Potential Rise，以 下，図中では，Transient GPR もしくは GPR と表記）およ び埋設地線を流れる電流の測定を行った。実験回路を図 1 , 図 2 に示す。

まず，図 1(a)に示す実験装置の配置について説明する。 埋設地線は, 地表面から $d(\mathrm{~m})$ の深さに, 長さ $L(\mathrm{~m})$ を 埋設した。この際，大地抵抗率 $\rho_{E}(\Omega \cdot \mathrm{m})$ が異なる条件と して，電中研塩原実験場に設置した試験回路で，測定する 季節を変化させて実験を実施した。なお，過渡電位上昇と 電流分布は，始端から $5 \mathrm{~m}$ 毎に測定点を設けて測定を行っ た。この時の導体の配置を図 1(b) に示す。

各部の過渡電位上昇および電流分布の測定は, 図 2 に示 す回路で行った。電流印加線は長さ $600 \mathrm{~m}$, 電圧測定補助 線は長さ $280 \mathrm{~m}$ とした。電流は, パルス発生器 $(\mathrm{PG})$ から 抵抗 $(300 \sim 2000 \Omega)$ を介して埋設地線に印加し，この時発 生する過渡電位上昇, 埋設地線に流れる電流をそれぞれ電 圧プローブ，CT で測定した。また，埋設地線の周波数特性 を測定する場合は，PGに代えてパワーアンプを伴った発信

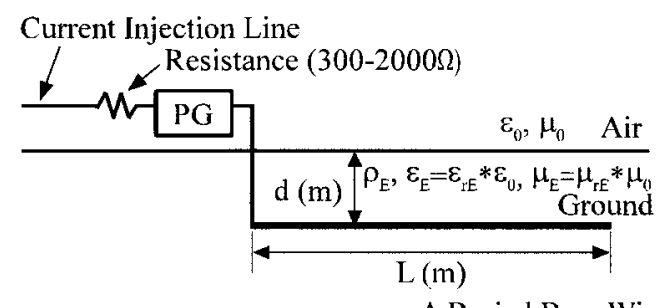

(a) Setup of measuring equipments

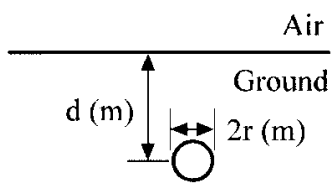

(b) Configuration of a buried bare wire

図 1 実験回路

Fig. 1. Experimental circuit.

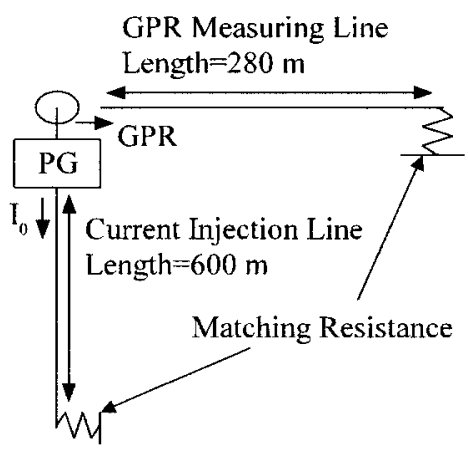

図 2 実験回路の配置

Fig. 2. Setup for experimental circuit.
表 1 測定装置性能一覧

Table 1. Specification of measuring equipments.

\begin{tabular}{|c|c|c|}
\hline Point & Type & Specification \\
\hline $\begin{array}{c}\text { Current } \\
\text { (Injection) }\end{array}$ & Pearson CT 411 & $\begin{array}{l}\text { Frequency: } 1 \mathrm{~Hz}-20 \mathrm{MHz} \\
\text { Sensitivity: } 0.05 \mathrm{~V} / \mathrm{A} \text { with } \\
50 \Omega \text { load }\end{array}$ \\
\hline $\begin{array}{c}\text { Current } \\
\text { (Distribution) }\end{array}$ & $\begin{array}{l}\text { Pearson CT } \\
3525\end{array}$ & $\begin{array}{l}\text { Frequency: } 5 \mathrm{~Hz}-15 \mathrm{MHz} \\
\text { Sensitivity: } 0.05 \mathrm{~V} / \mathrm{A} \text { with } \\
50 \Omega \text { load }\end{array}$ \\
\hline Voltage (GPR) & Tektronix P6009 & $\begin{array}{l}\text { Frequency: DC-120MHz } \\
\text { Sensitivity: 100:1 } \\
\text { Input Impedance: } 10 \mathrm{M} \Omega \\
\text { Input Capacitance: } 2.5 \mathrm{pF}\end{array}$ \\
\hline $\begin{array}{l}\text { Pulse } \\
\text { Generator }\end{array}$ & $\begin{array}{c}\text { Velonex Type } \\
360\end{array}$ & $\begin{array}{l}\text { Rise Time: } 20 \mathrm{~ns} \\
\text { Pulse Width: } 50 \mathrm{~ns}-3 \mathrm{~ms} \\
\text { Max. Voltage: } 2500 \mathrm{~V} \text { with } \\
\text { 200Sload }\end{array}$ \\
\hline $\begin{array}{l}\text { Power } \\
\text { Amplifier }\end{array}$ & $\begin{array}{l}\text { NF Electronic } \\
\text { Instrument } \\
\text { Type } 4025\end{array}$ & $\begin{array}{l}\text { Frequency: DC-1MHz } \\
\text { Max. Voltage: } 130 \mathrm{~V}^{-p} \\
\text { Output Impedance: } 150 \Omega\end{array}$ \\
\hline $\begin{array}{l}\text { Signal } \\
\text { Generator }\end{array}$ & $\begin{array}{c}\text { Hewlett } \\
\text { Packard } \\
8116 \mathrm{~A}\end{array}$ & $\begin{array}{l}\text { Frequency: } 1 \mathrm{mHz}-50 \mathrm{MHz} \\
\text { Output Impedance: } 50 \Omega \\
\text { Max. Voltage: } \pm 8 \mathrm{~V}\end{array}$ \\
\hline $\begin{array}{l}\text { Signal } \\
\text { Transmitter } \\
(\mathrm{E} / \mathrm{O}-\mathrm{O} / \mathrm{E})\end{array}$ & $\begin{array}{c}\text { Sony- Tektronix } \\
\text { A6904S }\end{array}$ & $\begin{array}{l}\text { Frequency: DC- } 100 \mathrm{MHz} \\
\text { Input Impedance: } 1 \mathrm{M} \Omega \\
\text { Input Level: } \pm 50 \mathrm{~V}- \pm 0.2 \mathrm{~V} \\
\text { Output: } \pm 1 \mathrm{~V}\end{array}$ \\
\hline $\begin{array}{c}\text { Digital Storage } \\
\text { Oscilloscope } \\
\text { (DSO) }\end{array}$ & Lecroy LC334A & $\begin{array}{l}\text { Frequency: DC-500MHz } \\
\text { Sampling: Max 500MS/s } \\
\text { Sensitivity: 8bits/word }\end{array}$ \\
\hline
\end{tabular}

器に取り替え, PG を用いた測定と同様な測定回路で過渡 電位上昇および電流の測定を行った。なお，各センサとデ ジタルオシロ間は, 光ケーブルで接続し, 多点での同時観 測を可能にした。測定に用いた装置の性能を表 1 に示す。

\section{3. 実験結果}

$\langle\mathbf{3} \cdot \mathbf{1}\rangle$ 実験結果の取りまとめ方法 鉄塔や送電線の雷 サージ応答特性を評価する場合, 直角波電流を印加した場 合に現れる過渡インピーダンスによって，その応答を評価 することが一般に行われている。このため，下記に示す数 值解析により，測定対象の直角波応答を求めることが多い。

$Z_{0}=L^{-1}\left[\frac{1}{s} \cdot \frac{L\{\text { Output }(t)\}}{L\{\operatorname{Input}(t)\}}\right]$

ここに, $L$ : ラプラス順変換, $L^{-1}$ : ラプラス逆変 換, $s=\alpha+j \omega, \alpha$ : 積分路変更定数, $\operatorname{Input}(t)$ :

入力信号, Output $(t)$ : 出力信号

本論文では，実験で得られた過渡電位上昇や電流分布を 出力信号とし, 印加電流を入力信号として, (1) 式を用いて 計算することで, 直角波電流に対する過渡電位上昇特性, 電 流分布特性を求めた。なお，この計算では文献 (17) (19) の相除法および数值ラプラス変換を採用した。

埋設地線の定常接地抵抗を考える場合, 重要なパラメー 夕として, 大地抵抗率が上げられる。一般的に，大地抵抗 率は, ウェンナーの 4 電極法を用いて測定することができ るが，測定が煩雑であるために，頻繁に測定を行うことが できない。一方，大地抵抗率は，土中の含水量に大きく影 響を受けるために，土中条件によって大きく変化すること 
が知られている(20)。このため，天候の影響を受けやすい野 外での実験では，測定ケースに対応した大地抵抗率を正確 に把握することは極めて難しい。

そこで本論文では，それぞれの測定ケースに対応する大 地抵抗率を Sunde が与えた埋設地線の定常接地抵抗值の計 算式を用いて推定することとした ${ }^{(3)}$ 。(2) 式に Sunde の計 算式を示す。

$$
\rho_{E}=\frac{R \cdot \pi \cdot L}{\left\{\ln \frac{2 L}{\sqrt{2 r d}}-1\right\}}
$$

(2) 式で, 埋設地線の埋設深さ $d(\mathrm{~m})$, 導体半径 $r(\mathrm{~m})$ 扔 よび埋設地線長 $L(\mathrm{~m})$ は既知であり, 定常接地抵抗 $R(\Omega)$ を代入することで，大地抵抗率を求めることができる。

本論文では, 定常接地抵抗 $R$ は, 測定時間が十分経過し, 過渡電位上昇が飽和した時点での值（電流印加後約 $40 \mu \mathrm{s}$ 経 過後の過渡電位上昇值）とした。なお，この值は，接地抵 抗計で得られる接地抵抗值とほほ一致することを別途確認 している。

次に，埋設地線の過渡特性を考える場合に必要な大地パ ラメータとして, 大地の比誘電率が上げられる。比誘電率 の測定法としては，平衡ストリップ線路にサンプル土壤を 組み入れ，その周波数特性から比誘電率を求める方法が提 案されているが(21)，土壤の含水量によって大きく影響を受 けるために，野外での実験で測定することは，極めて難し く，実用的な測定法とは言い難い。

そこで，本論文では，埋設地線が土中に埋設されている ことに着目して, 埋設地線を比誘電率 $\varepsilon_{r E}$ の誘電体に取り 囲まれた導体と考元，真空中の光の伝搬速度との比較から 次式によりその值を推定した。

$$
\begin{aligned}
& \varepsilon_{r E}=\left(\frac{c_{0}}{c_{1}}\right)^{2} \ldots \ldots \ldots \ldots \ldots \ldots \ldots \ldots \ldots \ldots \ldots \ldots \ldots \ldots \ldots \ldots \ldots \ldots \\
& \text { ここに, } c_{0}: \text { 真空中の光の伝搬速度 }\left(=3 \times 10^{8} \mathrm{~m} / \mathrm{s}\right), \\
& c_{1} \text { : 埋設地線中央点で測定した伝搬速度 }
\end{aligned}
$$

〈3・2〉 埋設地線の過渡電位上昇および電流分布特性

断面積 $S=22 \mathrm{~mm}^{2}$ の埋設地線を表層から $d=50 \mathrm{~cm}$ の 位置に長さ $L=40 \mathrm{~m}$ で埋設し, 直角波電流を印加した際に 発生する各部の過渡電位上昇抢よび電流分布の測定を行っ た。図 3 に代表的測定結果を示す。なお，図中の距離は, 始端（電流印加点）からの位置を示す。

まず過渡電位上昇の比較であるが，図 3 での比較で明ら かなように，埋設地線の始端では，時間初期において，80 程度の過渡電位上昇が観測された後に過渡電位上昇が減少 し，時間経過に伴って，定常接地抵抗に収束する傾向が観 察される。一方，電流分布について比較すると，始端から の距離が大きくなるにつれて，最大值，収束值とも減少す る様相が観測される。

次に，大地抵抗率の影響について検討する。図 4 は，埋 設地線の始端（電流印加点）での過渡電位上昇の比較結果

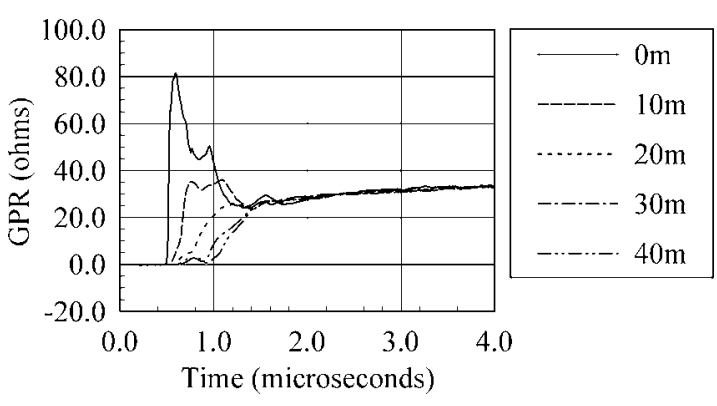

(a) Transient GPR distribution

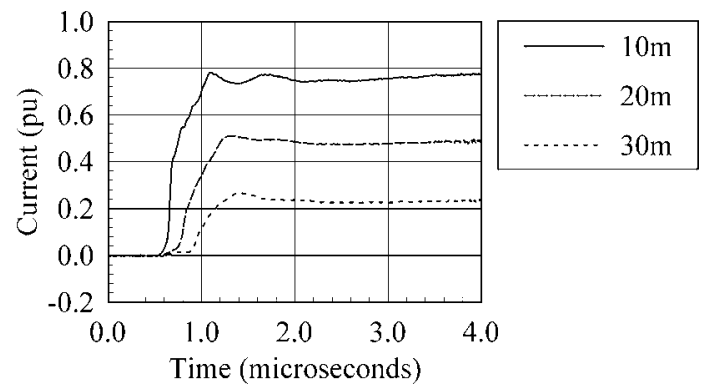

(b) Current distribution

$L=40 \mathrm{~m}, \quad S=22 \mathrm{~mm}^{2}, \quad d=50 \mathrm{~cm}, \rho_{E}=720 \Omega \cdot \mathrm{m}, \quad \varepsilon_{r E}=16.9, \quad R=36.4 \Omega$

図 3 過渡電位上昇と電流分布の測定結果

Fig. 3. Measured results of transient GPR and current distributions.

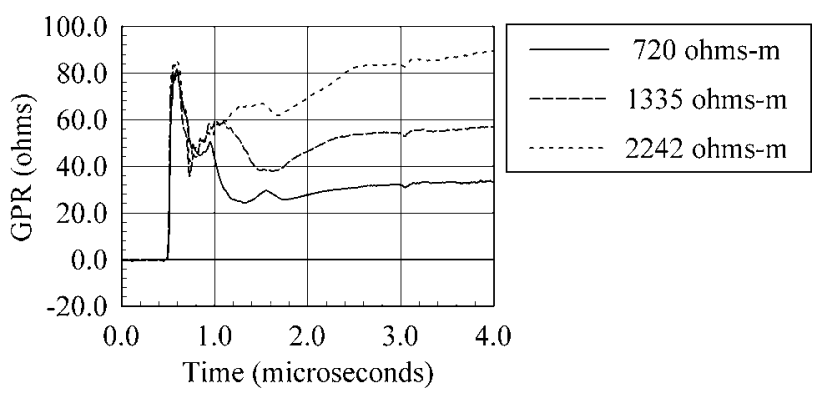

$L=40 \mathrm{~m}, \quad S=22 \mathrm{~mm}^{2}, \quad d=50 \mathrm{~cm}, \quad \varepsilon_{r E}=12.8-16.9, \quad R=36.4-113.3 \Omega$

図 4 大地抵抗率の影響

Fig. 4. Effects of ground resistivity.

を示す。この比較で明らかなように，大地抵抗率に対する 過渡電位上昇の変化は，時間初期に現れる過渡電位上昇最 大值が大地抵抗率に関わらずほぼ一定であるのに対して, 時間経過後，定常接地抵抗に収束するまでの特性は，大地 抵抗率の大小によって変化することが観測される。

次に，埋設地線の伝搬速度の代表的な測定結果を図 5 に 示す。伝搬速度は，始端と中央点での電流波形の到達時間 差から求めた。この結果, 伝搬速度は, 大地抵抗率に関わ らず概ね 70 $80 \mathrm{~m} / \mu \mathrm{s}$ であることがわかった。

$\langle\mathbf{3} \cdot \mathbf{3}\rangle$ 埋設地線長の差異の影響 埋設地線長の過渡 電位上昇に与える影響について検討を行った。この結果を 図 6 に示す。図中の $L$ の值は, 埋設地線長を示す。この結 果，埋設地線長が大きくなるにつれて，過渡電位上昇の収 束值が減少するのに対して, 時間初期に発生する過渡電位 上昇最大值は，長さに関わらず一定であることが観測され 


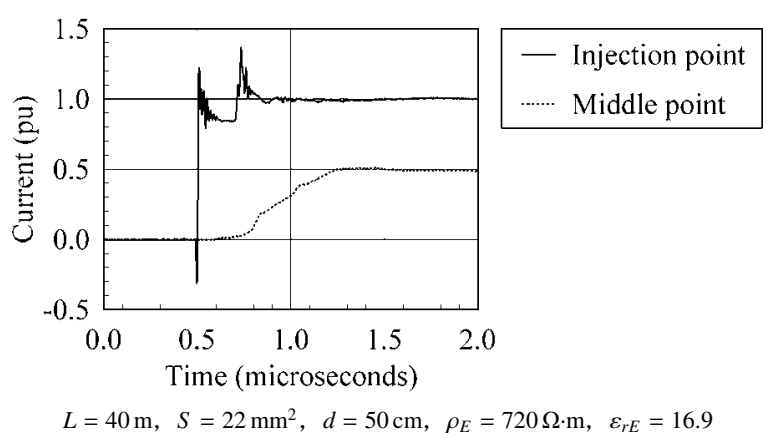

図 5 電流伝搬速度の測定結果

Fig. 5. Measured result of current propagation velocity.

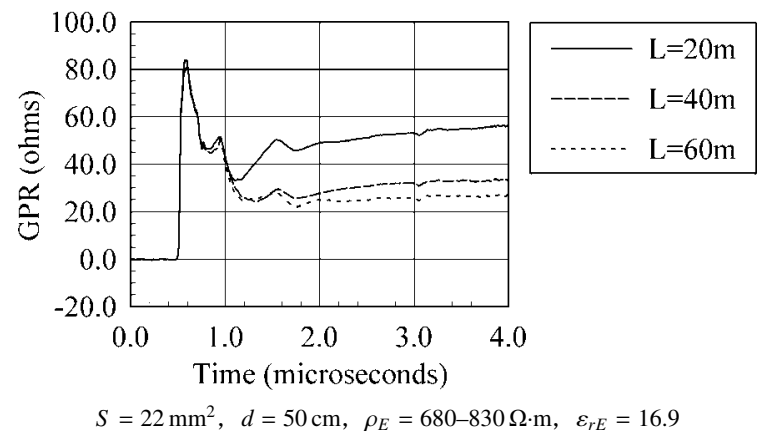

図 6 埋設地線長の影響

Fig. 6. Effects of wire length.

る。この傾向は，大地抵抗率が変化しても同様に成立する ことは別途確認している。これらの特性から考えると，時 間初期に発生する最大值は, 埋設地線のサージインピーダ ンスと言うべきものであり，埋設地線に固有の定数と見な すことができる。

$\langle\mathbf{3} \cdot \mathbf{4}\rangle$ 周波数特性 埋設地線の周波数特性は, 接地抵 抗の定常から過渡に至る特性を把握する上で重要な測定項 目といえる。測定は, 図 1, 図 2 の実験回路で PG を発信器 とパワーアンプで構成される可変周波数電源に変更して行っ た。埋設地線は, 断面積 $S=22 \mathrm{~mm}^{2}$, 埋設深さ $d=50 \mathrm{~cm}$, 長さ $L=20,40,60 \mathrm{~m}$ とし, この埋設地線に $10 \mathrm{~Hz} \sim 1 \mathrm{MHz}$ の可変周波数電流を印加し, 埋設地線の始端で発生する電 圧を測定した。この時得られた電圧と電流の比から，入力 インピーダンスを求めた。なお，この測定で得られる入力 インピーダンスは, 埋設地線を分布定数回路と考えると, 境 界条件 $\left(I=I_{0}\right.$ at $x=0, I=0$ at $\left.x=L\right)$ から，(4) 式に示 す分布定数回路の終端開放時の入力インピーダンスに相当 することがわかる。図 7 に埋設地線長 $L=60 \mathrm{~m}$ 時の測定 結果を示す。

$$
Z_{\text {in }}=\frac{V(0)}{I(0)}=\frac{V(0)}{I_{0}}=Z_{0} \frac{1+\exp (-2 \Gamma L)}{1-\exp (-2 \Gamma L)}=Z_{m} \cdot e^{j \varphi}
$$

この測定結果から，埋設長 $60 \mathrm{~m}$ の埋設地線の周波数特性 には，次のような特性があることがわかった。

（1） 入力周波数が低周波数領域（約 $70 \mathrm{kHz}$ 以下の場

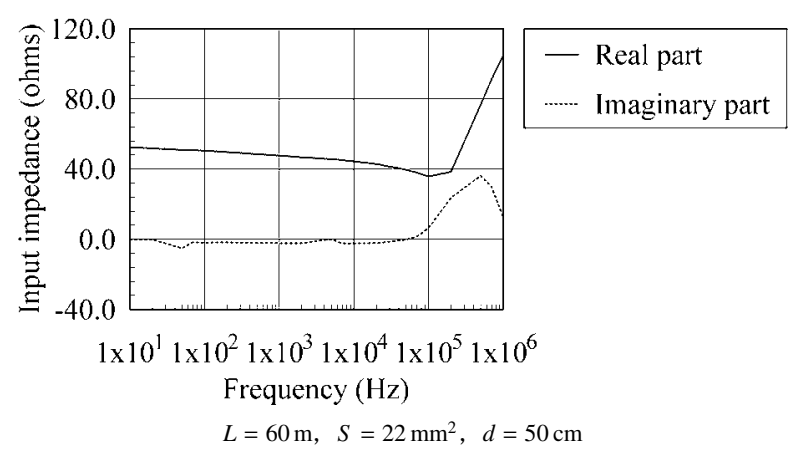

図 7 埋設地線の周波数特性

Fig. 7. Frequency characteristics of a buried bare wire.

合）では, 入力インピーダンスの実部は, 周波数の増加に 伴い減少する。一方, 虚部は負の值を示すが, その変化は, 小さい。ただし，実部と虚部の大小を比較した場合，実部 が虚部に比べて十分大きいために，入力インピーダンスは， 概ね純抵抗回路として見なされる。

（2） 入力周波数が中周波数領域 $(70 \mathrm{kHz} \sim 500 \mathrm{kHz}$ の 範囲）では, 入力インピーダンスの実部は, さらに減少を 続ける。一方, 虚部は周波数の増加に伴い変化し, 正の值 を示す。実部と虚部の大小を比較した場合, 実部が多少大 きいものの低周波数領域に比べ虚部が無視できない。従っ て，入力インピーダンスは， $\mathrm{R}+\mathrm{jX}$ で表現される。

（3）入力周波数が高周波数領域 $(500 \mathrm{kHz}$ を越える場 合）では, 入力インピーダンスの実部は, 減少から増加に転 ずる。一方, 虚部は, 周波数の変化に伴って変動する。この 様な变化は, 分布定数回路の共振現象の影響と考えられる。

この様な周波数特性は，埋設地線長にかかわらず同様な 傾向を示すことを別途確認している。従って, 埋設地線の 過渡電位上昇特性を考える場合は, その分布定数回路とし ての特性を考慮する必要があることを示している。

\section{4. 実験結果と理論式との比較}

〈4・1〉埋設地線定数の理論式 図 1(b)に示す配置で, 埋設地線のインピーダンスおよびアドミタンスの理論式は, Sundeにより次式が与えられている ${ }^{(3)}$ 。

$$
\left.\begin{array}{l}
Y(\Gamma)=\left\{Y_{C}^{-1}+Y_{E}^{-1}\right\}^{-1} \cong Y_{E}, \quad Z(\Gamma)=Z_{C}+Z_{E} \\
\Gamma=\sqrt{Z(\Gamma) \cdot Y(\Gamma)}, \quad Z_{0}=\sqrt{Z(\Gamma) / Y(\Gamma)}
\end{array}\right\}
$$

ここに, $Y(\Gamma)$ : 線路アドミタンス $(\mathrm{S} / \mathrm{m}), Y_{C}$ : 導体 内部アドミタンス $(\mathrm{S} / \mathrm{m}), Y_{E}$ : 大地帰路アドミタ ンス $(\mathrm{S} / \mathrm{m}), Z(\Gamma)$ : 線路インピーダンス $(\Omega / \mathrm{m})$, $Z_{C}$ : 導体内部インピーダンス $(\Omega / \mathrm{m}), Z_{E}$ : 大地 㱕路インピーダンス $(\Omega / \mathrm{m}), \Gamma$ : 伝搬定数 $(1 / \mathrm{m})$, $Z_{0}$ : 特性インピーダンス $(\Omega)$, なお, $Y_{C}$ は導体と 大地との接触面のアドミタンスであり通常は無視 される。 
ここで, 大地帰路アドミタンス $Y_{E}$, 導体内部インピーダ ンス $Z_{C}$ ， 大地帰路インピーダンス $Z_{E}$ は，それぞれ次式で 与えられる。

(a) $Y_{E}$ : 大地帰路アドミタンス ${ }^{(3)}$

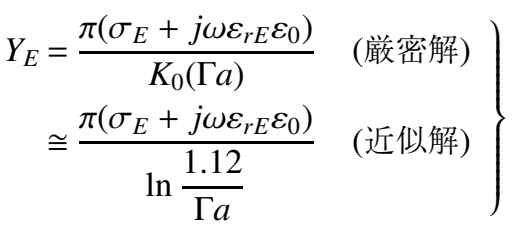

ここに, $\sigma_{E}$ : 大地導電率 $(\mathrm{S} / \mathrm{m}), \sigma_{E}=1 / \rho_{E}, \rho_{E}$ : 大地抵抗率 $(\Omega \cdot \mathrm{m}), \omega=2 \pi f, f$ : 周波数 $(\mathrm{Hz})$, $\varepsilon_{r E}:$ 大地の比誘電率, $\varepsilon_{0}:$ 真空中の誘電率, $K_{0}$ : 第 2 種変形ベッセル関数，第 1 階

(b) $Z_{C}$ : 導体内部インピーダンス ${ }^{(22)}$

$Z_{C}=\frac{j \omega \mu_{r c} \mu_{0}}{2 \pi x} \frac{I_{0}(x)}{I_{1}(x)}$

ここに, $\rho_{c}$ : 導体の抵抗率 $(\Omega \cdot \mathrm{m}), \mu_{r c}$ : 導体の比透 磁率, $\mu_{0}$ : 真空中の比透磁率, $I_{0}, I_{1}$ : 第 1 種ベッセ 儿関数, 第 0 階㧍よび第 1 階, $x=r / \sqrt{\rho_{c} / j \omega \mu_{r c} \mu_{0}}$, $r$ : 導体半径, $S=\pi r^{2}$ : 導体の断面積

(c) $Z_{E}$ : 大地帰路インピーダンス ${ }^{(3)}$

$$
\begin{aligned}
Z(\Gamma)= & \frac{j \omega \mu_{r E} \mu_{0}}{\pi a \gamma^{2}}\left[\Gamma \cdot K_{1}(\Gamma a)\right. \\
& \left.-\left(\gamma^{2}+\Gamma^{2}\right)^{1 / 2} K_{1}\left(a \sqrt{\gamma^{2}+\Gamma^{2}}\right)\right] \quad \text { (厳密解) } \\
\cong & \frac{j \omega \mu_{r E} \mu_{0}}{2 \pi} \ln \frac{1.85}{a \sqrt{\gamma^{2}+\Gamma^{2}}} \quad \text { (近似解) }
\end{aligned}
$$

ここに, $\mu_{r E}$ : 大地の比透磁率, $K_{1}$ : 第 2 種変形ベッ セル関数, 第 1 階, $\gamma=\sqrt{j \omega \mu_{r E} \mu_{0}\left(\sigma_{E}+j \omega \varepsilon_{r E} \varepsilon_{0}\right)}$

さて，これらの理論式で用いられている $a$ は，導体の位 置関係を示し, 半径 $r$ の導体が深さ $d$ で埋設されている場 合，次式により与えられる。

$$
a=\sqrt{r \sqrt{r^{2}+(2 d)^{2}}} \cong \sqrt{2 r d} \text { (近似解: } d \gg r \text { ) }
$$

(5)〜 (8) 式で明らかなように $Y$ および $Z$ は，架空線の場 合と異なり，伝搬定数 $\Gamma$ の関数として与えられる。従って, $\Gamma$ を収束計算により求めることで $Y$ および $Z$ を決定し，代 表的測定結果との比較を行った。

$\langle\mathbf{4} \cdot \mathbf{2}\rangle$ 周波数特性の比較

周波数特性の比較結果を 図 8 に示す。この比較では, Sunde の理論式（厳密解を利 用）による解を理論解として表示している。また，従来の 検討では，導体内部インピーダンスは，通常無視されてき たが，この妥当性についても検討する。

この比較で明らかなように，内部インピーダンスの考慮 の有無に関わらず，理論解と実測結果は，ほぼ良好に一致す

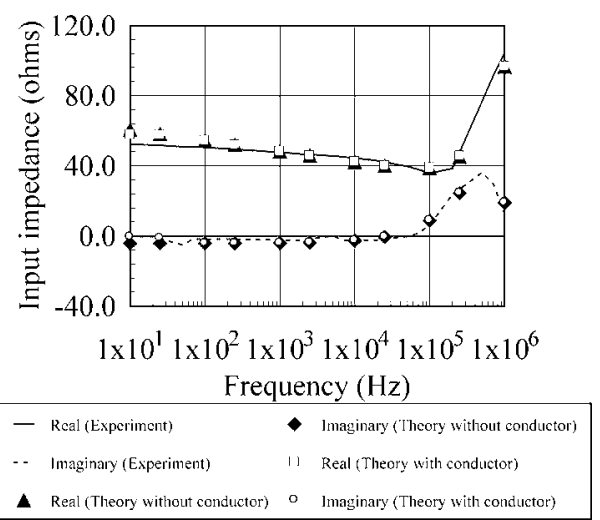

計算大地抵抗率 $: \rho_{E}=1015 \Omega \cdot \mathrm{m}$, 計算大地比誘電率 $: \varepsilon_{r E}=14.0$, $L=60 \mathrm{~m}, S=22 \mathrm{~mm}^{2}, d=50 \mathrm{~cm}$

図 8 周波数特性の実験結果と理論解の比較結果

Fig. 8. Comparison between experimental and theoretical results of frequency characteristics.

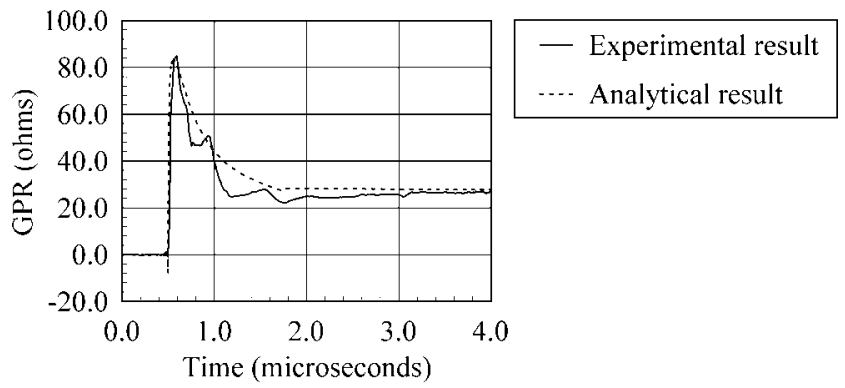

計算大地抵抗率 : $\rho_{E}=750 \Omega \cdot \mathrm{m}$, 計算大地比誘電率 : $\varepsilon_{r E}=20$, $L=60 \mathrm{~m}, S=22 \mathrm{~mm}^{2}, d=50 \mathrm{~cm}$

図 9 実験結果と解析結果の比較

Fig. 9. Compared results between experimental and analytical results.

る。この結果は, 理論式による解析は, 埋設地線の特性を 精度よく再現できることを示している。しかしながら，低 周波数領域では, 内部インピーダンスを考慮した方が実測 結果とよく一致することから, 以下の解析では, 導体の内 部インピーダンスを考慮した解析を行う。

$\langle\mathbf{4} \cdot \mathbf{3}\rangle$ 過渡電位上昇特性の比較 ここでは，埋設地 線の始端に打ける過渡電位上昇について, 実験結果と解析 結果との比較を行う。数值解析にあたっては, 周波数領域 解に数值ラプラス逆変換を施すことによって時間領域解を 求めた。また, 解析には埋設地線の定数として, 厳密解に よる值を用いた。この比較結果を図 9 に示す。

この比較で明らかなように, Sunde の理論式による解析 結果は，実験結果を概ね再現していることがわかる。従っ て, Sunde の理論式に基づく解析は, 実用に供することがで きると考えられる。また, Sunde の理論式で厳密解と近似 解の比較であるが，その差異はわずかであり，近似解を用 いた解析でも問題ないことを別途確認している。なお，大 地抵抗率と比誘電率は，実験結果から推定する必要がある ために，今後，これらの定数の測定方法を含めた検討が必 
要と考えられる。

\section{5. まとめ}

本論文では，埋設地線の過渡特性を実験的・理論的に検 討し, 次の結論を得た。

（1）実験結果から埋設地線の特性として，時間初期に 現れる過渡電位上昇最大值は，大地抵抗率や埋設地線長に 関わらずほぼ一定である。この特性は，埋設地線にも架空 線と同様にサージインピーダンスが存在することを示して いる。

（2）実験結果から埋設地線内の電流伝搬速度は，大地 抵抗率に関わらず，概ね $70 \sim 80 \mathrm{~m} / \mu \mathrm{s}$ と推定される。

（3）可変周波数電源を用いた測定から，埋設地線は周 波数特性を有することがわかった。特に，高周波数領域に おいては，分布定数回路として振る舞う。

（4）Sunde の理論式による解析結果と実験結果の比較 を行い，理論式は実験結果を概ね再現できることを明らか とした。しかしながら，大地抵抗率と比誘電率は，実験結 果から推定する必要があるために，今後測定方法を含めた 検討が必要と考えられる。

(平成 17 年 9 月 22 日受付)

\section{文献}

(1) 電気学会:「雷サージ評価高度化のためのモデリング」, 電気学会技 術報告, No.704 (1998)

(2) H. Motoyama: "Fundamental Study on Lightning Protection Design for Transmission System", CRIEPI Report, T56 (1998) (in Japanese) 本山英器:「電力系統における耐雷設計のための基礎的研究」, 電中 研総合報告, T56 (1998)

(3) E.D. Sunde: "Earth Conduction Effects in Transmission Systems", Dover Publications, Inc., New York (1968)

(4) S.S. Devgan and E.R. Whitehead: "Analytical Models for Distributed Grounding Systems", IEEE Trans. Power Apparatus Syst., Vol.PAS-92, No.5, pp.1763-1770 (1973)

(5) R. Verma and D. Mukhedkar: "Impulse Impedance of Ground Wire", IEEE Trans. Power Apparatus Syst., Vol. PAS-99, No.5, pp.2003-2007 (1980)

(6) B.R. Gupta and B. Thapar: "Impulse Impedance of Grounding Grids", IEEE Trans. Power Apparatus Syst., Vol.PAS-99, No.6, pp.2357-2362 (1980)

(7) A.P. Meliopoulos and M.G. Moharam: "Transient Analysis of Grounding Systems", IEEE Trans. Power Apparatus Syst., Vol.PAS-102, No.2, pp.389399 (1983)

(8) R. Velazques and D. Mukhedkar: "Analytical Modelling of Grounding Electrodes Transient Behavior", IEEE Trans. Power Apparatus Syst., Vol.PAS103, No.6, pp.1314-1322 (1984)

(9) L. Grcev and F. Dawalibi: "An Electromagnetic Model for Transients in Grounding Systems", IEEE Trans. Power Delivery, Vol.5, No.4, pp.17731781 (1990)
(10) F.E. Menter and L. Grcev: "EMTP-Based Model for Grounding System Analysis", IEEE Trans. Power Delivery, Vol.9, No.9, pp.1838-1849 (1994)

11) S. Karaki, T. Yamazaki, K. Nojima, T. Yokota, H. Murase, H. Takahashi, and S. Kojima: "Transient Impedance of GIS Grounding Grid", IEEE Trans. Power Delivery, Vol.10, No.2, pp.723-731 (1995)

12) L.D. Grcev: "Computer Analysis of Transient Voltages in Large Grounding Systems", IEEE Trans. Power Delivery, Vol.11, No.2, pp.815-823 (1996)

(13) R. Elarbi, S. Kato, and K. Mizobe: "Transients Grounding Impedance of Electrode Elements for Grounding Mat", T. IEE Japan, Vol.117-B, No.3, pp.364-370 (1997-3)

14) L.D. Grcev and M. Heimbach: "Frequency Dependent and Transient Characteristics of Substation Grounding Systems", IEEE Trans. Power Delivery, Vol.12, No.1, pp.172-178 (1997)

(15) M. Heimbach and L.D. Grcev: "Grounding System Analysis in Transients Programs Applying Electromagnetic Field Approach", IEEE Trans. Power Delivery, Vol.12, No.1, pp.186-193 (1997)

(16) M. Heimbach and L.D. Grcev: "Simulation of Grounding Structures within EMTP", Proc. of 10th International Symposium on High Voltage Engineering in Montreal, Vol.5, pp.131-135 (1997)

(17) T. Kato and K. Iwamoto: "Application of the Stabilized Inverse-convolution Method of Frequency Domain for the Error Correction of Impulse Potential Divider", T. IEE Japan, Vol.105-B, No.3, pp.195-202 (1985-3) (in Japanese)

加藤利次・岩本國三 :「インパルス電圧分圧器の変歪誤差補正への周 波数領域安定化相除法の適用」, 電学論 B, 105,3, pp.195-202 (1985-3)

18) N. Nagaoka and A. Ametani: "A Development of a Generalized Frequencydomain Program-FTP", IEEE Trans. Power Delivery, Vol.3, pp.19962004 (1988)

(19) A. Ametani: "The Application of the Fast Fourier Transform to Electrical Transients Phenomena", Int. J. Elect. Eng. Educ., Vol.10, pp.277-281 (1973)

(20) Subcommittee for Power Stations and Substations: "Guide to Lightning Protection Design of Power Stations, Substations and Underground Transmission Lines-Part V Grounding System Design of Power Stations and Substations-", CRIEPI Report, T40 (1995) (in Japanese) 耐雷設計委員会発変電分科会：「発変電所㧍よび地中送電線の耐雷 設計ガイド一第 $\mathrm{V}$ 編発変電所の接地設計一」, 電中研総合報告, $\mathrm{T} 40$ (1995)

(21) Y. Amano and K. Tanabe: "Study on Propagation Characteristics Underground Electromagnetic Wave (1)—Method for Measuring Propagation Constant of Electromagnetic Wave in Rocks-", CRIEPI Report T89065 (1990) (in Japanese)

天野雄二・田辺一夫：「地盤の電磁波伝搬特性に関する検討 (I)—岩 盤の電磁波伝搬定数の測定法とその検討一」, 電中研研究報告 T89065 (1990)

(22) S.A. Schelkunoff: "The Electromagnetic Theory of Coaxial Transmission Line and Cylindrical Shields", Bell Syst. Tech. J., Vol.13, pp.532-579 (1934)

本 山 英 器 (正員) 1961 年 10 月 8 日生。1987 年 3 月同志社

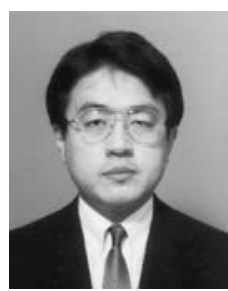
大学大学院工学研究科電気工学専攻博士課程（前 期）修了。1987 年 4 月電力中央研究所入所, 現 在に至る。主として, 電力系統の過渡現象解析, モデリング，過渡現象の測定，理論解析，電力設 備の耐雷設計に関する研究に従事。博士 (工学)。 IEEE 会員。 